\title{
Hubungan Tingkat Stres dengan Dismenore Primer pada Mahasiswi Tahun Pertama Fakultas Kedokteran
}

\author{
Almira Rosyidika Sriwati ${ }^{1}$, Ermawati $^{2}$, Laila Isrona ${ }^{3}$ \\ ${ }^{1}$ Fakultas Kedokteran Universitas Andalas Padang \\ ${ }^{2}$ Bagian Obgyn Fakultas Kedokteran Universitas Andalas Padang \\ ${ }^{3}$ Bagian Pendidikan Kedokteran Fakultas Kedokteran Universitas Andalas Padang
}

A B S T R A C T

\begin{abstract}
Latar Belakang. Dismenore primer merupakan keluhan ginekologis yang sering terjadi pada remaja di dunia. Dismenore primer akan berdampak pada kualitas hidup, dapat menurunkan konsentrasi belajar seseorang karena nyeri yang dirasakan. Salah satu faktor risiko dismenore primer adalah stres.

Objektif. Penelitian ini dilakukan untuk mengetahui hubungan antara tingkat stres dengan dismenore primer pada mahasiswi tahun pertama program studi kedokteran angkatan 2018 Fakultas Kedokteran Universitas Andalas.
\end{abstract}

Metode. Desain penelitian yang digunakan adalah cross sectional dengan teknik total sampling dengan jumlah sampel 146 orang. Data responden diperoleh dari kuisioner. Data dianalisis menggunakan Uji Fisher.

Hasil. Hasil penelitian menunjukan lebih dari separuh responden tidak stres $(65,1 \%)$ dan tidak dismenore primer (93, $8 \%)$. Hasil analisis bivariat menunjukan tidak terdapat hubungan antara tingkat stres dengan dismenore primer dengan $p=0,720(p>0,05)$.

Kesimpulan. Kesimpulan penelitian ini adalah sebagian besar mahasiswi tahun pertama tidak mengalami dismenore primer dan tidak stres. Tidak terdapat hubungan antara tingkat stres dengan dismenore primer.

Kata kunci: stres, dismenore primer, mahasiswi tahun pertama.

Background. Primary dysmenorrhea is a gynecological complaint that often occurs in adolescents in the world. Primary dysmenorrhea will have an impact on the quality of life, can reduce the concentration of learning because of the pain. One of the risk factors for primary dysmenorrhea is stress. Objective. This study was conducted to determine the relationship between stress levels and primary dysmenorrhea in the first year female medical students of the 2018 registered year at the Medical Faculty of Andalas University.

Method. A cross-sectional study design with a total sampling technique was used with 146 people of the total sample. Respondents' data were obtained from questionnaires. Data were analyzed by using the Fisher test.
Result. The results showed that more than half of the respondents were not stressed (65.1\%) and neither have primary dysmenorrhea (93.8\%). The results of the bivariate analysis showed that there was no correlation between stress levels and primary dysmenorrhea with $p=0.720(p>0.05)$.

Conclusion. The conclusion of this study is most of the firstyear female medical did not experience primary dysmenorrhea and were not stressed. There is no relationship between stress levels with primary dysmenorrhea.

Keywords: stress, primary dysmenorrhea, first-year female students

\section{Apa yang sudah diketahui tentang topik ini?}

$90 \%$ dari remaja putri didunia mengalami dismenore dan lebih dari 50\% wanita haid mengalami dismenore primer. $^{7}$ Prevalensi yang lebih besar pada umumnya pada wanita muda, dengan perkiraan berkisar antara $67 \%$ sampai $90 \%$ untuk perempuan yang berusia 17-24 tahun. ${ }^{4}$

\section{Apa yang ditambahkan pada studi ini?}

Penelitian tentang keterkaitan stres dengan dismenore primer pada mahasiswi tahun pertama program studi kedokteran masih sedikit.

\section{CORRESPONDING AUTHOR}

Name: Almira Rosyidika Sriwati

Phone: +6282176772865

E-mail: almirarosyidika22@gmail.com

\section{ARTICLE INFORMATION}

Received: September $23^{\text {rd }}, 2020$

Revised: October $15^{\text {th }}, 2020$

Available online: October $31^{\text {st }}, 2020$ 


\section{Pendahuluan}

Dismenore merupakan masalah ginekologi yang paling umum yang dialami wanita baik remaja maupun dewasa yang akan berdampak pada kesehatan reproduksi wanita. ${ }^{1}$ Dismenore berasal dari bahasa Yunani, yaitu dysmenorrhea, terdiri atas "dys" berarti sulit, "meno" berarti bulan, dan "rrhea" berarti aliran. ${ }^{2}$ Dismenore adalah nyeri yang berlebihan saat menstruasi/ kram pada abdomen bawah yang dapat terjadi 24 jam sebelum perdarahan haid dan dapat bertahan selama 24-36 jam disertai dengan gejala seperti berkeringat, sakit kepala, mual, muntah.3,4,5 Dismenore terbagi menjadi dismenore primer dan dismenore sekunder. Dismenore primer adalah nyeri haid tanpa disertai kelainan panggul, sedangkan dismenore sekunder nyeri haid yang berkaitan dengan kelainan panggul. ${ }^{5}$ Dismenore memiliki dampak besar pada kualitas hidup, produktivitas kerja, absensi, interaksi sosial dan dapat juga menimbulkan kerugian ekonomi yang cukup besar karena biaya pengobatan, perawatan medis. 5,6

Dismenore sangat umum terjadi, terutama dikalangaan remaja putri. Sekitar $90 \%$ dari remaja putri didunia mengalami dismenore dan lebih dari $50 \%$ wanita haid mengalami dismenore primer. $^{7}$ Prevalensi yang lebih besar pada umumnya pada wanita muda, dengan perkiraan berkisar antara $67 \%$ sampai $90 \%$ untuk perempuan yang berusia 17-24 tahun. ${ }^{4}$ Di Indonesia, angka kejadian dismenore pada remaja putri pada tahun 2008 sebanyak $64,25 \%$ terdiri dari $54,89 \%$ dismenore primer dan 9,36\% dismenore sekunder. ${ }^{8}$ Penyebab dasar dari dismenore primer ditandai dengan peningkatan kontraktilitas uterus dengan amplitudo kontraksi yang tinggi yang diakibatkan oleh meningkatnya sintesis dan sekresi prostaglandin $\mathrm{F}_{2 \alpha \cdot} .^{9}$

Faktor risiko dismenore primer yaitu menarche dini, IMT tinggi, nulipara, menstruasi yang lama, adanya riwayat keluarga dengan dismenore dan stres. ${ }^{5}$ Dismenore terjadi pada kondisi yang menimbulkan stres pada kelompok umur 18-24 tahun. Semakin tinggi skor ansietas, depresi dan stress (DASS; Depression Anxiety Stress Scale) maka semakin tinggi resiko kejadian dismenore. ${ }^{9}$

Stres merupakan respon nonspesifik tubuh atau reaksi terhadap lingkungan yang mengganggu seseorang. Stres juga merupakan proses menerima dan mengatasi terhadap ancaman dan tantangan yang ada di lingkungan. ${ }^{10}$ Penelitian yang dilakukan di Mesir, Universitas Fayom didapatkan $62,4 \%$ mahasiswa mengalami stres dari 442 mahasiswa. ${ }^{11}$ Berdasarkan penelitian yang dilakukan di Universitas Sumatera Utara stres pada mahasiswa kedokteran dari 90 sampel didapatkan gambaran tingkat tingkat stres sebesar $71 \% .^{12}$

Mahasiswa program studi kedokteran memiliki stressor yang tinggi. ${ }^{10}$ Akademik, finansial, karir, gaya hidup, dan tuntutan sosial dari kehidupan mahasiswa kedokteran sering dihubungkan dengan masalah psikologi yang dialami mahasiswa kedokteran. ${ }^{11}$ Sumber stres mahasiswa kedokteran dapat timbul dari dalam diri (internal) maupun dari luar (eksternal) seperti ruangan kuliah yang tidak nyaman, besarnya tuntutan orang tua terhadap prestasi akademik, sistem pembelajaran yang berbeda, lingkungan pertemanan yang tidak nyaman, dan lainnya. ${ }^{12}$ Bagi mahasiswa kedokteran, stres merupakan suatu tantangan, terutama pada mahasiswa tahun pertama. Dukungan dari keluarga dalam mengurangi stres sangat diperlukan. ${ }^{13}$ Stres pada mahasiswa kedokteran tahun pertama memiliki tingkat stres lebih tinggi dari pada tahun setelahnya, terutama pada saat menjelang ujian dan lingkungan yang sangat kompetitif. ${ }^{13}$ Faktor lain yang dapat menyebabkan stres pada mahasiswa tahun pertama adalah adaptasi dengan kurikulum yang baru yaitu PBL, mempertahankan kompetensi diri, hubungan dengan teman seangkatan, dan tinggal jauh dari rumah. ${ }^{14}$

Penelitian tentang keterkaitan stres dengan dismenore primer pada mahasiswi tahun pertama program studi kedokteran masih sedikit. Maka dari itu, penulis tertarik untuk meneliti hubungan antara tingkat stres dengan dismenore primer pada mahasiswi tahun pertama program studi kedokteran angkatan 2018 Fakultas Kedokteran Universitas Andalas.

\section{Metode}

Jenis penelitian ini adalah analitik observasional dengan menggunakan desain penelitian cross sectional. Penelitian ini dilakukan setelah mendapat kelayakan etik (ethical clearance) dari Komisi Etik Penelitian Fakultas 
Kedokteran Universitas Andalas dengan nomor surat 509/ KEP/ FK/ 2018.

Penelitian ini dilakukan untuk mengetahui hubungan tingkat stres dengan dismenore primer pada mahasiswi tahun pertama program studi kedokteran angkatan 2018 Fakultas kedokteran Universitas Andalas. Sampel penelitian adalah semua mahasiswi aktif program studi kedokteran angkatan 2018 Fakultas Kedokteran Universitas Andalas yang memenuhi kriteria inklusi dan ekslusi. Data diperoleh dari pengisian keisioner oleh responden. Analisis data dengan univariat dan bivariat menggunakan Fisher.

\section{Hasil}

\section{Analisis Univariat}

Penelitian dilakukan pada bulan September sampai Desember 2018. Setelah dilakukan penyebaran kuesioner, didapatkan yang memenuhi kriteria inklusi sebanyak 146 dan 29 tidak memenuhi kriteria inklusi.

Tabel 1. Distribusi Responden Berdasarkan Usia, Tingkat Stres, dan Kejadian Dismenore Primer

\begin{tabular}{llcc}
\hline Variabel & Kategori & Jumlah & Persentase \\
\hline Usia & 15 & 1 & 0,7 \\
& 16 & 3 & 2,1 \\
& 17 & 33 & 22,6 \\
& 18 & 80 & 54,8 \\
& 19 & 26 & 17,8 \\
Tingkat & 20 & 3 & 2,1 \\
stres & Normal & 95 & 65,1 \\
& Stres ringan & 21 & 14,4 \\
& Stres sedang & 19 & 13,0 \\
& Stres berat & 10 & 6,8 \\
& Stres Sangat & 1 & 0,7 \\
Kejadian & berat & & \\
dismenore & Tidak & 137 & 93,8 \\
primer & dismenore & & \\
& primer & & \\
& Dismenore & 9 & 6,2 \\
\hline
\end{tabular}

Tabel 1 menunjukan distribusi usia responden yang terbanyak adalah 18 tahun (54,8\%), dengan usia termuda 15 tahun $(0,7 \%)$. Sebagian besar dari responden tidak mengalami stres yaitu sebanyak 95 orang $(65,1 \%)$. Pada responden yang mengalami stres, tingkatan yang terbanyak adalah stres ringan 21 orang $(14,4 \%)$ sedangkan stres sedang sebanyak 19 orang $(13,0 \%)$, stres berat 10 orang $(6,8 \%)$ dan stres sangat berat 1 orang $(0,7 \%)$. Responden yang tidak mengalami dismenore primer adalah sebanyak 137 orang
$(93,8 \%)$, sedangkan yang mengalami dismenore primer sebanyak 9 orang $(6,2 \%)$.

\section{Analisis Bivariat}

Berdasarkan uji statistik, hubungan tingkat stres dengan dismenore primer pada mahasiswi tahun pertama angkatan 2018 FKUA dapat dilihat pada tabel 2 dibawah ini :

Tabel 2. Distribusi Responden Menurut Tingkat Stres dan Dismenore Primer

\begin{tabular}{lccccccc}
\hline Stres & \multicolumn{2}{c}{ Dismenore Primer } & \multirow{2}{*}{ Total } & \multirow{2}{*}{-value } \\
\cline { 2 - 6 } & \multicolumn{2}{c}{ Ya } & \multicolumn{2}{c}{ Tidak } & \multicolumn{2}{c}{} & \\
\cline { 2 - 7 } & $\mathbf{n}$ & $\mathbf{\%}$ & $\mathbf{n}$ & $\mathbf{\%}$ & $\mathbf{n}$ & $\mathbf{\%}$ & \\
\hline Tidak & 5 & 5,3 & 90 & 94,7 & 95 & 100 & 0,720 \\
Ya & 4 & 7,8 & 47 & 92,2 & 51 & 100 & \\
Total & 9 & 6,2 & 137 & 93,8 & 146 & 100 & \\
\hline
\end{tabular}

Analisis data pada tabel 2 menunjukan mahasiswi yang tidak stres, banyak dialami oleh responden yang tidak mengalami dismenore primer yaitu 90 orang $(94,7 \%)$. Mahasiswi yang mengalami stres dengan dismenore primer sebanyak 4 orang $(7,8 \%)$. Sedangkan pada mahasisiwi yang stres dan tidak mengalami dismenore primer sebanyak 47 orang $(92,2 \%)$. Berdasarkan hasil analisis bivariat didapatkan $\mathrm{p}=0,720$, dimana $\mathrm{p}>0,05$ Sehingga, dapat disimpulkan tidak terdapat hubungan antara tingkat stres dengan dismenore primer pada mahasiswi tahun pertama program studi kedokteran angkatan 2018 Fakultas Kedokteran Universitas Andalas.

\section{Pembahasan}

\section{Tingkat Stres}

Berdasarkan tabel 1 mayoritas mahasiswi tahun pertama angkatan 2018 tidak mengalami stres $(65,1 \%)$. Tingkat stres yang paling banyak ditemukan adalah stres tingkat ringan $(14,4 \%)$.

Waktu yang dihabiskan untuk belajar di Universitas dianggap sebagai salah satu periode yang paling membuat stres. Stres akademik juga dipengaruhi oleh tingkat kreativitas mahasiswa. Semakin rendah tingkat kreativitas, maka semakin tinggi stres yang disebabkan oleh lingkungan akademik. ${ }^{13}$

Stres akademik mahasiswi tahun pertama Fakultas Kedokteran Universitas Andalas tahun disebabkan oleh stressor yang cukup banyak dibandingkan stressor di sekolah, diantaranya ujian blok, tutorial, jadwal skill lab, pratikum, 
mata kuliah wajib dan umum di hari Sabtu, kegiatan kaderisasi kampus, banyaknya tugas perkuliahan, lokasi perkuliahan di dua tempat. ${ }^{15}$

Stres yang dialami oleh seseorang tidak sepenuhnya berkaitan dengan hal negatif, tetapi dapat menjadi hal yang positif yang artinya stres dapat menjadi suatu tantangan untuk mengatasi tuntutan yang dihadapinya, contohnya meningkatkan kualitas diri dan prestasi belajar. ${ }^{12}$

\section{Dismenore Primer}

Dari penelitian ini didapatkan frekuensi kejadian dismenore primer pada mahasiswi tahun pertama angkatan 2018 sebanyak (6,2 \%) dan lebih dari separuh (93,8 \%) mahasiswi tidak mengalami dismenore primer.

Kemungkinan banyak faktor yang mempengaruhi kejadian dismenore antara lain menarche dini, IMT yang berlebih, nulipara, menstruasi yang lama, adanya riwayat keluarga dengan dismenore dan stres. ${ }^{5}$ Stres dapat mempengaruhi kejadian dismenore, stres dapat menghambat pengeluaran FSH dan LH sehingga dapat mengganggu perkembangan dari folikel luteum menyebabkan sintesis progesteron berkurang, dan produksi prostaglandin meningkat. 5,17

\section{Hubungan Tingkat Stres dengan Dismenore Primer}

Berdasarkan tabel 2 hasil analisis bivariat dengan menggunakan uji Fisher didapatkan $p=0,720 \quad(p>0,05)$. Hal ini menunjukkan tidak terdapat hubungan antara tingkat stres dengan dismenore primer.

Secara teori stres dapat mempengaruhi kejadian dismenore primer, dimana ketika stres terjadi pelepasan Corticotrophin Releasing Hormone (CRH), CRH akan merangsang hipofisis anterior untuk mengeluarkan ACTH. ${ }^{18}$ Selanjutnya ACTH akan merangsang korteks adrenal untuk mengeluarkan kortisol.18 Stres juga dapat menghambat pengeluaran FSH dan LH yang akan menyebabkan terganggunya perkembangan folikel. Sehingga dapat mempengaruhi sintesis dan pelepasan progesteron yang akan mempengaruhi aktivitas prostaglandin. ${ }^{17}$ Prostaglandin dapat menyebabkan peningkatan kontraksi uterus sehingga terjadi iskemia pada uterus. ${ }^{19}$
Hasil penelitian ini tidak sesuai dengan teori diatas. Penelitian ini mendapatkan yang stres 51 orang, namun kelompok yang mengalami dismenore primer dengan stres sebanyak 4 orang dan 5 orang mengalami dismenore primer tanpa adanya stres. Banyak faktor yang mempengaruhi dismenore primer selain stres, seperti menarche dini, IMT tinggi, nulipara, menstruasi yang lama, adanya riwayat keluarga dengan dismenore. Berdasarkan tabel 1 yang mengalami dismenore primer sebanyak 9 (6,2 \%) orang, hal ini dapat disebabkan ambang nyeri setiap orang yang berbeda-beda. ${ }^{20}$ Diperlukan penelitian lain untuk mengetahui penyebab dismenore pada mahasiswi FK Unand tahun pertama.

\section{Kelemahan dan Hambatan Penelitian}

Kekurangan penelitian ini adalah tidak menilai faktor risiko lainnya yang berhubungan dengan dismenore primer. Hambatan penelitian yang menggunakan kuisioner tidak dapat mengukur kejujuran responden dan akurasi data saat mengisi kuisioner yang bergantung dengan daya ingat responden. Selain itu penelitian stres dengan kuisioner bersifat tidak tetap karena bergantung dengan suasana hati dan tidak dapat mengukur kadar kortisol secara langsung.

\section{Simpulan}

Tidak terdapat hubungan antara tingkat stres dengan dismenore primer pada mahasiswi tahun pertama angkatan 2018 Fakultas Kedokteran Universitas Andalas ( $p>0,05)$.

\section{Ucapan Terima Kasih}

Terima kasih kepada seluruh responden mahasiswi tahun pertama program studi kedokteran angkatan 2018 yang telah memberikan kontribusi dalam penelitian ini.

\section{Daftar Pustaka}

1. Larasati TA, Alatas F. Dismenore primer dan faktor risiko dismenore primer pada remaja. Majority. 2016; 5(3): 79-84.

2. Madhubala C, Jyoti, K. Relation between dysmenorrhea and body mass index in adolescents with rural versus an urban variation. The Journal of Obstetrics and Gynecology of India. 2012; 62(4): 442-5.

3. Hendarto H. Gangguan haid. In: Anwar M, editors. Ilmu kandungan, 3rd ed. Jakarta : PT Bina Pustaka Sarwono Prawirohardjo; 2011. p.161-83.

4. Hendrik. Problema haid. Cetakan 1. Solo: PT Tiga Serangkai Pustaka Mandiri; 2006. 
5. Ju H, Jones M, Mishra G. The prevalence and risk factors of dysmenorrhea. Epidemiologic Reviews. 2014; 36: 104-13.

6. Joshi T, Kural M, Agrawal DP, Noor NN, Patil A. Primary dysmenorrhea, and its effect on the quality of life in young girls. International Journal of Medical Science and Public Health. 2015; 4: 381-5.

7. Berkley KJ. Primary dysmenorrhea: an urgent mandate. International Association for the Study of Pain. 2013; 21(3): 1-8.

8. Santoso. Angka Kejadian Nyeri Haid pada Remaja Indonesia. Journal of Obstetrics \& Gynecology. 2008; 3(1) 1-7.

9. Naik P, Tanna AS, Mudaliar PN, Tari AD. Variations of dysmenorrhea during stress and non-stress condition in college going girls in Belgaum city: A cross-sectional study. International Journal of Physiotherapy and Research. 2015; 3(2): 1012-6

10. Habeeb KA. Prevalence of stress among medical students at Taibah University. Journal of Taibah University Medical Science. 2010; 5(2): 110-9.

11. Wahed WYA, Hassan SK. Prevalence and associated factors of stress, anxiety, and depression among medical Fayom University students. Alexandria Journal of medicine. 2017; 53(1): 77-84.

12. Carolin. Gambaran tingkat stres pada mahasiswa pendidikan sarjana kedokteran (skripsi). Medan: Universitas Sumatera Utara: 2010.

13. Nechita F, Dan N, Mihail CP, Ion R. Stress in medical students. Rom J Morphol Embryol. 2014; 55 (3): 1263-6.

14. Moffat KJ, Mcconnachie A, Ross S, Morrison JM. Firstyear medical student stress and coping in a problem-based learning medical curriculum. Medical Education. 2004; 38(5): 482- 91.

15. Tusa'diyah H. Hubungan tingkat stres akademik dengan oligomenore pada mahasiswi tahun pertama pendidikan dokter Universitas Andalas tahun 2017 (Skripsi). Padang: Fakultas Kedokteran Universitas Andalas; 2018.

16. Desmita. Hubungan antara Stres Sekolah dengan Derajat Stres dan Strategi Penanggulangan pada Siswa MAN Model Bukittinggi. Universitas Padjajaran (Tesis). Bandung: Universitas Padjajaran; 2005.

17. Katwal PC, Karki NR, Sharma P, Tamrakar SR. Dysmenorrhea, and stress among the Nepalese medical students. Kathmandu University medical journal. 2016; 14(4): 318-21.

18. Alkadhi K. Brain Physiology and Pathophysiology in Mental Stres: Review Article. Journals of Hindawi. 2013; 1-23.

19. Anurogo D, Wulandari A. Cara jitu mengatasi nyeri haid. Yogyakarta: ANDI Yogyakarta. 2011.

20. Farastuti D, Windiastuti E. Penanganan nyeri pada keganasan. Sari Pediatri. 2005; 7(3): 153-159. 